\title{
Synthesis of 1,3,4-Thiadiazoles, $\alpha$-Pyranone, Pyridine, Polysubstituted Benzene from 1,3,4-Thiadiazolyl Ethanone and Testing Against Tuberculosis Based on Molecular Docking Studies
}

\author{
MAHMOUD. M. ABDELALL ${ }^{1,2}$ \\ ${ }^{1}$ Department of Chemistry, Faculty of Science, Al-Azhar University, Nasr City11884, Cairo, Egypt. \\ ${ }^{2}$ Department of Chemistry, Faculty of Science and Art, Al-Baha University, Al-Baha, Saudi Arabia. \\ Corresponding author E-mail: abdelall_sci@yahoo.com \\ http://dx.doi.org/10.13005/ojc/300321
}

(Received: May 30, 2014; Accepted: July 01, 2014)

\begin{abstract}
The synthesis is reported of new 1,3,4-thiadiazole, imidazopyridine, á-pyranone, pyrazolo[1,5-a]pyrimidine, polysubstituted benzene, pyridine , pyrazoles and pyrazolo[3,4-d]pyridazine using 1-\{(5Z)-5-[(4-methoxyphenyl)imino]-4-phenyl-4,5-dihydro-1,3,4-thiadiazol-2-yl\}ethanone as starting material.
\end{abstract}

Key words: 1,3,4-thiadiazole, enaminone, dithioester, polysubstituted benzene.

\section{INTRODUCTION}

1,3,4-Thiadiazoles have been screened for their antibacterial and antifungal activities ${ }^{1-4}$, anti-inflammatory ${ }^{5}$, anti-tuberculosis activity ${ }^{6}$. The development of efficient methods for the synthesis of 1,3,4-thiadiazoles has attracted significant interest. Substituted 1,3,4-thiadiazoles have become very useful compounds in medicine, agriculture, and in many fields of technology such as dyes ${ }^{7}$, lubricating compositions $^{8}$, optically active liquid crystals ${ }^{9}$, photographic materials ${ }^{10}$, and many others. Also, applications of 1,3,4- thiadiazoles in agriculture as herbicides ${ }^{11}$, fungicides ${ }^{12}$, and bacteriocides ${ }^{13}$ have been patented. Also, 1,3,4-thiadiazole derivatives have shown anti-inflammatory activity ${ }^{14-16}$.

\section{RESULTS AND DISCUSSION}

\section{Chemistry}

The synthetic strategies adopted to obtain the target compound are depicted in Schemes1. The key intermediate $1-\{(5 Z)-5-[(4-$ methoxyphenyl) imino]-4-phenyl-4,5-dihydro1,3,4-thiadiazol-2-yl\}ethanone (3) was prepared in an excellent yield by condensing methyl (4-methoxyphenyl) carbamodithioate(1) with (1E)2-oxo-N-phenylpropanehydrazonoyl chloride (2). 
the structure of $\mathbf{3}$ was established on the basis of analytical and spectral data. The ${ }^{1} \mathrm{HNMR}$ spectrum showed signals at 2.61(s,3H, $\left.\mathrm{COCH}_{3}\right) 3.81(\mathrm{~s}, 3 \mathrm{H}$
,OCH$\left.{ }_{3}\right) 6.91,6.97$ (dd, 4H, Ar-H AB-system ) 7.36 - 8.01 (m,5H,ArH).

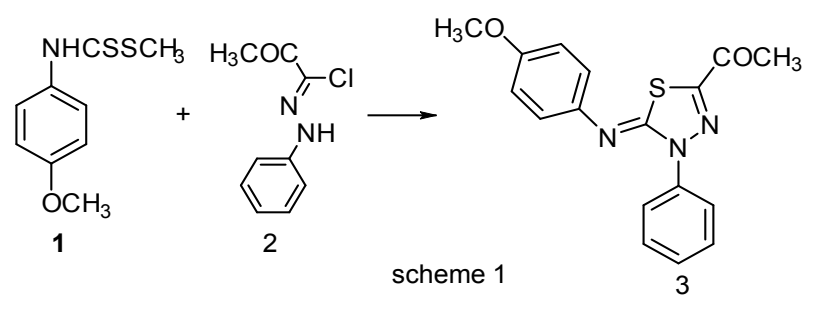

Scheme 1:
Treatment of 1-\{(5Z)-5-[(4-methoxyphenyl) imino]-4-phenyl-4,5-dihydro-1,3,4-thiadiazol2-yl\}ethanone (3) with methyl/ or benzyl hydrazinecarbodithioate ${ }^{17,18}$ in ethanol at reflux condenser afforded the corresponding dithioesters $(4 a, b)$. The ${ }^{1}$ HNMR spectrum of $4 a$ showed signals at $\delta=2.37\left(\mathrm{~s}, 3 \mathrm{H}, \mathrm{CH}_{3}-\mathrm{C}=\mathrm{N}\right), 2.62(\mathrm{~s}, 3 \mathrm{H}$, $\left.\mathrm{SCH}_{3}\right), 3.73\left(\mathrm{~s}, 3 \mathrm{H}, \mathrm{OCH}_{3}\right), 7.16-7.97(9 \mathrm{H}, \mathrm{m}, \mathrm{Ar}-$ $\mathrm{H}), 9.99 \mathrm{ppm}(\mathrm{s}, 1 \mathrm{H}, \mathrm{NH})$. while ${ }^{1} \mathrm{HNMR}$ spectrum of $4 \mathrm{~b}$ showed signals at $\delta=2.41\left(\mathrm{~s}, 3 \mathrm{H}, \mathrm{CH}_{3}-\mathrm{C}=\mathrm{N}\right)$, $3.77\left(\mathrm{~s}, 3 \mathrm{H}, \mathrm{OCH}_{3}\right), 4.53\left(\mathrm{~s}, 2 \mathrm{H}, \mathrm{SCH}_{2}\right), 7.10-7.93(14 \mathrm{H}$, $\mathrm{m}, \operatorname{Ar}-\mathrm{H}), 9.93 \mathrm{ppm}(\mathrm{s}, 1 \mathrm{H}, \mathrm{NH})$.

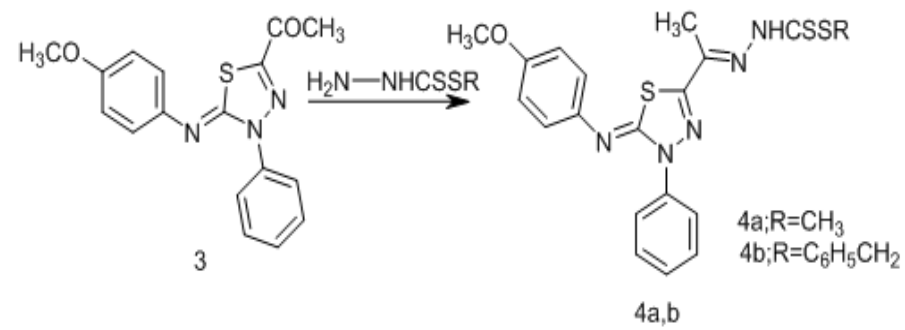

Scheme 2:

Interaction of methyl dithioester (4a) with hydrazonoyl halides $(5 a, b)^{19,20}$ in ethanol containing triethylamine at reflux temperature gave bis -1,3,4-thiadiazoles $(8 a, b)$. The structure of 8 was deduced from their spectral data and elemental analysis, Scheme (3). The ${ }^{1} \mathrm{HNMR}$ spectrum of $8 \mathrm{a}$ showed signals at ä=2.32(s, 3H, $\left.\mathrm{CH}_{3} \mathrm{CO}\right), 2.49$ (s, $\left.3 \mathrm{H}, \mathrm{CH}_{3}-\mathrm{C}=\mathrm{N}\right), 3.78\left(\mathrm{~s}, 3 \mathrm{H}, \mathrm{OCH}_{3}\right), 7.02$ - $7.99 \mathrm{ppm}$ $(14 \mathrm{H}, \mathrm{m}, \mathrm{Ar}-\mathrm{H})$.Similarly, benzyldithioester (4b) reacted with the former hydrazonyl halides $(5 a, b)$ and produced products which were found to be identical in all respects (m.p, mixed m.p and spectra) with $(8 a, b)$. The formation of (8) can be explained via elimination of methyl mercaptan (or benzyl mercaptan) from the corresponding cycloadduct (7), which is assumed to be formed from 1,3-dipolar cycloaddition of nitrile imides (prepared in situ from 5 and triethylamine) to the $\mathrm{C}=\mathrm{S}$ double bond in (4a) or (4b), (Scheme 3).

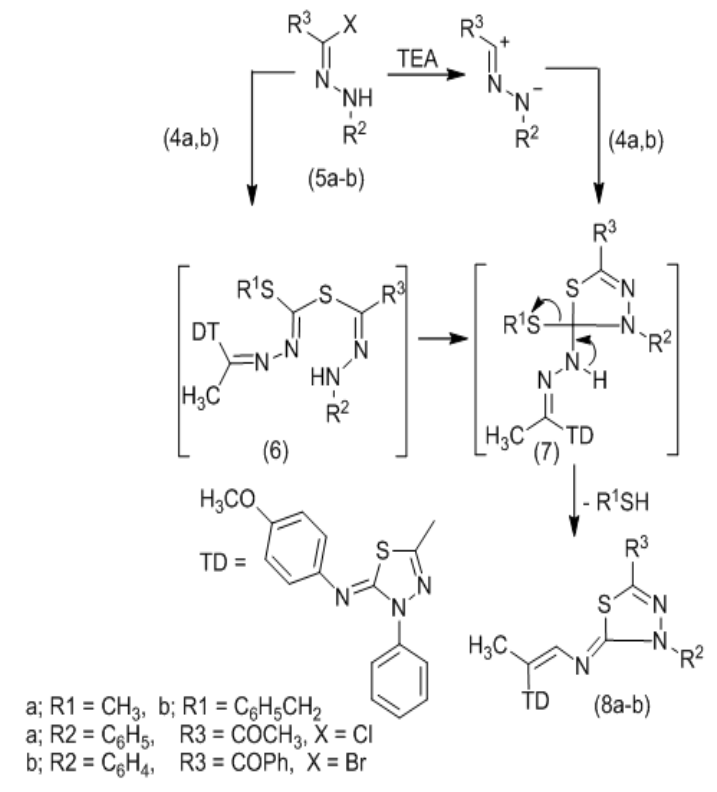

Scheme 3: 
Enaminones are readily obtainable reagents and constitute an interesting class of compounds that are versatile precursors for the synthesis of several heterocyclic aromatic compounds. Thus, treatment of equimolar quantities of 1-\{(5Z)-5-[(4-methoxyphenyl)imino]-4-phenyl- 4,5-dihydro-1,3,4-thiadiazol-2-yl\}ethanone (3) with dimethylformamide-dimethylacetal (DMF-DMA) in refluxing xylene afforded the corresponding enaminone as (2E)-3-(dimethylamino)-1-\{(5Z)-5-[(4methoxyphenyl)imino]-4-phenyl-4,5-dihydro-1,3,4thiadiazol-2-yl\}prop-2-en-1-one (9) (Scheme 4).

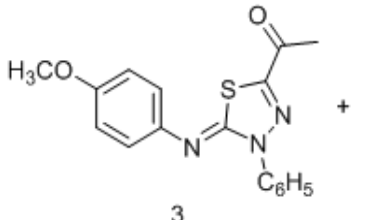<smiles>COc1ccc(/N=c2\sc(C(=O)C=CN(C)C)nn2-c2ccccc2)cc1</smiles>

\section{Scheme 4:}

${ }^{1} \mathrm{H}-\mathrm{NMR}(\delta \mathrm{ppm})$ spectrum $\left(\mathrm{CDCl}_{3}\right)$ indicated signals at : 2.96 and $3.17\left(2 \mathrm{~s}, 6 \mathrm{H}, \mathrm{N}\left(\mathrm{CH}_{3}\right)_{2}\right)$ , $3.81\left(\mathrm{~s}, 3 \mathrm{H}, \mathrm{OCH}_{3}\right), 5.90$ and $7.85(\mathrm{dd}, 2 \mathrm{H}$, olefinic $\mathrm{CH}=\mathrm{CH} ; \mathrm{J}=12 \mathrm{~Hz}$ ), which support that the structure in (E-form), not (Z-form), $6.89,7.02$ (dd, 4H, Ar-H AB-system ) $7.27-8.03(\mathrm{~m}, 5 \mathrm{H}, \mathrm{ArH})$.Enaminone (9) reacted with acetylglycine and benzoyl-glycine in acetic anhydride to give a products that were identified as $\mathrm{N}$-(6-\{(5Z)-5-[(4-methoxyphenyl) imino]-4-phenyl-4,5-dihydro-1,3,4-thiadiazol-2-yl\}-2oxo-2H-pyran-3-yl)acetamide and $\mathrm{N}-(6-\{(5 Z)-5-[(4-$ methoxyphenyl)imino]-4-phenyl-4,5-dihydro-1,3,4thiadiazol-2-yl\}-2-oxo-2H-pyran-3-yl)-benzamide $(10 a, b)$ respectively, which confirmed on the basis of elemental analysis and spectral data, (Scheme $5)$.<smiles>[R]C(=O)Nc1ccc(-c2nn([13CH3])c(=Nc3ccc(OC)cc3)s2)oc1=O</smiles>

Scheme 5: 


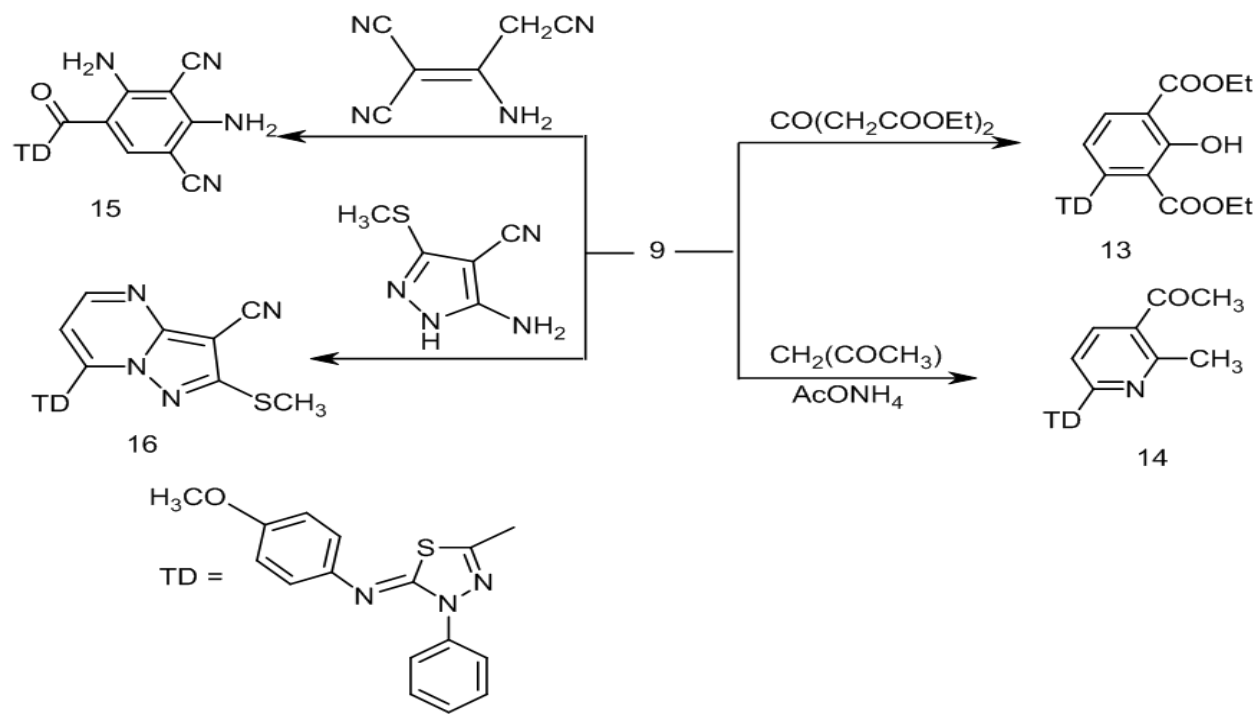

Scheme 6:

Interaction of enaminone (9) with 1,4-benzoquinone and 2-cyanomethylbenzimidazole afforded 11 and 12 respectively, (Scheme $5)$.condensation of enaminone (2) with diethyl acetonedicarboxylate in refluxing acetic acid afforded tetrasubstituted benzene derivative (13) (Scheme 6) ${ }^{1} \mathrm{HNR}$ of 13 showed signals at $\delta=1.25,1.43(2 \mathrm{t}, 6 \mathrm{H}$ , $2 \mathrm{CH}_{2} \mathrm{CH}_{3}$ ), 3.82(s ,3H , $\left.\mathrm{OCH}_{3}\right), 4.31,4.44$ (q , 4H ,2 $\left.\mathrm{CH}_{2} \mathrm{CH}_{3}\right), 6.92-7.94(\mathrm{~m}, 11 \mathrm{H}, \mathrm{Ar}-\mathrm{H})$ and 11.30ppm. (s $, 1 \mathrm{H}, \mathrm{OH})$.
Furthermore, reaction of enaminone 9 with other active methylene such as pentane-2,4dione and 2-aminoprop-1-ene-1,1,3-tricarbonitrile afforded pyridine (14) and polysubstituted benzene (15) derivatives, respectively(Scheme 6).

Next, the reaction of enaminone 9 with heterocyclic amines was investigated. Refluxing of enaminone 9 with 5-amino-3-(methylsulfanyl)-1 Hpyrazole-4-carbonitrile in glacial acetic acid gave 7-\{(5E)-5-[(4-methoxyphenyl)imino]-4-phenyl-4,5-<smiles>CCOC(=O)c1ccc(-c2nn([13CH3])c(=Nc3ccc(OC)cc3)s2)nc1C</smiles>

Scheme 7: 
dihydro-1,3,4-thiadiazol-2-yl\}-2-(methylsulfanyl) pyrazolo[1,5-a]-pyrimidine-3-carbonitrile (16) via elimination of water and dimethyl amine molecules (Scheme 6) . Condensation of enaminone 9 with ethyl 3-oxobutanoate were carried out in glacial acetic acid in the presence of ammonium acetate furnished a single product, for which the two possible structures 17 and 18 can be investigated (Scheme 7 ), but elemental analyses and spectral data were in complete accordance with the pyridinecarboxylate structure 18 .The IR spectrum of compound 18 revealed the absence of hydroxy band. Its ${ }^{1} \mathrm{H}-\mathrm{NMR}$ spectrum revealed a signals at $\delta 1.42\left(\mathrm{t}, 3 \mathrm{H}, \mathrm{CH}_{2} \mathrm{CH}_{3}\right.$ ) and 4.41( $\left.\mathrm{q}, 2 \mathrm{H}, \mathrm{CH}_{2} \mathrm{CH}_{3}\right)$ corresponding to ethyl ester protons, The structures of the products were confirmed by spectral (IR, MS and $1 \mathrm{H}-\mathrm{NMR}$ ) and elemental analyses (see Experimental).

Finally, hydrazonyl halides $5 a, b$ has been reported to add to $\alpha, \beta$-unsaturated carbonyl compounds to yield a mixture of isomeric pyrazolines ${ }^{21,22}$ In the present work the reaction of enaminone (9) with nitrileimine $(19 a, b)$ (generated in situ from the treatment of the hydrazonoyl halide $(5 a, b)$ with triethylamine in refluxing $m$-xylene) gave only one isolable product (TLC). From which two proposed structures $21 \mathrm{a}, \mathrm{b}$ or $23 \mathrm{a}, \mathrm{b}$ seemed possible, (Scheme 8). ${ }^{1} \mathrm{H}-\mathrm{NMR}$ spectrum provided a firm support for structure 23 and ruled out the other possible structure 21 . Thus, ${ }^{1} \mathrm{H}-\mathrm{NMR}$ spectrum of $23 \mathrm{a}$ and $23 \mathrm{~b}$ exhibits a singlet at 8.52 and at $8.57 \mathrm{ppm}$, respectively which indicates the presence of pyrazole $\mathrm{H}-5$ rather than $\mathrm{H} 4^{23}$. Pyrazole derivative (23) was assumed to be formed via initial 1,3-dipolar cycloaddition of nitrileimine (19) to the activated double bond in compound 9 forming non isolable intermediate (22) followed by the loss of dimethylamine, (Scheme 8). Treatment of pyrazole $23 a$ with hydrazine afforded pyrazolopyrdazine derivative 24 (Scheme 8).<smiles>[R]C(=O)c1cc(C(=O)[O-])n(-c2ccccc2)n1</smiles>

Scheme 8: 


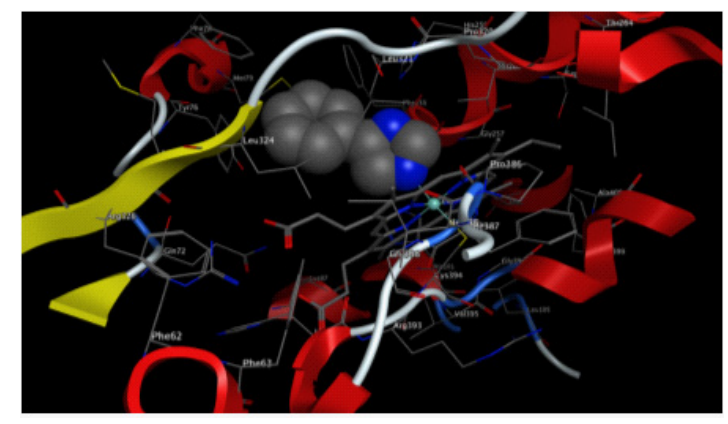

Fig. 1: The reference ligand was Docked into the active site of (14DM) using MOE tool

\section{Molecular Modeling \\ Docking studies}

From analysis X-ray crystal structure of cytochrome P450 14á-sterol Demethylase (14DM) from Mycobacterium in complex with 4-phenylimidazole[24], through interaction with amino acid residues of (14DM), and demonstrated that, His259 have a structural and functional evidence for the importance for inhibiting action of protein[24]. In order to obtained biological data on a structural basis, through rationalized ligand-protein interaction behavior, the molecular docking into the active site of

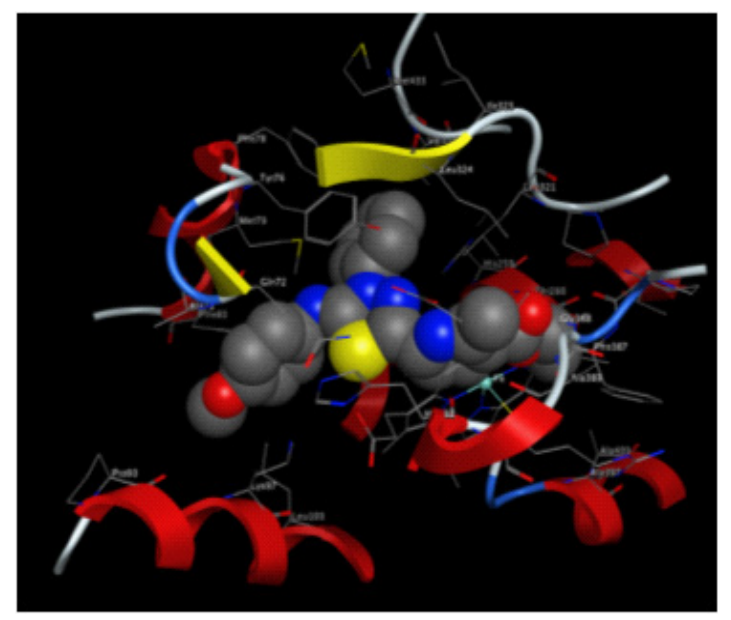

Fig. 2: The most active compound (15) was Docked into the active site of (14DM) using MOE tool

(14DM) from Mycobacterium was performed for the synthesized compounds using flexible method. All calculations for docking experiment were preformed with MOE 2008.10 [24]. The tested compounds were evaluated in silico (docking), using $X$-ray crystal structures of (PDB entry code 1E9X) ${ }^{24}$ ) complexes with phenylimidazole. The tested compounds were docked into active sites of both enzymes (14DM). The active site of the enzyme was defined, to include residues within a $10.0 \AA$ radius to any of the inhibitor atoms. The scoring functions were applied

Table 1: Docking energy scores $(\mathrm{kcal} / \mathrm{mol})$ derived from the MVD with MOE for isolated ligands

\begin{tabular}{lllllll}
\hline Cpd. & dG. & Int. & RMS & Eele & Evdw & Esol \\
\hline Phl. & -26.0351 & 3.193799 & 95.23377 & -139.165 & -7.95581 & -26.0351 \\
4a & -21.0712 & 3.914539 & 99.93333 & -133.194 & -7.7933 & -21.0712 \\
4b & -20.4332 & 4.223453 & 86.55226 & -125.737 & -8.2444 & -20.4332 \\
7 & -14.3858 & 3.191954 & 102.4845 & -140.062 & -7.40395 & -14.3858 \\
$8 \mathrm{a}$ & -13.5928 & 2.508745 & 103.7931 & -130.306 & -7.42558 & -13.5928 \\
$8 \mathrm{~b}$ & -13.0549 & 2.940189 & 97.62733 & -142.638 & -7.74488 & -13.0549 \\
9 & -5.78828 & 2.954836 & 123.0663 & -127.364 & -7.46471 & -5.78828 \\
13 & -1.74115 & 2.371951 & 98.83379 & -135.789 & -8.26996 & -1.74115 \\
14 & 10.81352 & 2.485482 & 118.7838 & -132.579 & -7.74696 & 10.81352 \\
15 & -22.8476 & 2.506386 & 47.70938 & -110.788 & -9.0488 & -22.8476 \\
16 & -22.2682 & 3.111174 & 52.53077 & -122.735 & -8.35606 & -22.2682 \\
\hline
\end{tabular}

d.G.: free binding energy of the ligand from a given conformer, Int.: binding energy of hydrogen bond interaction with receptor, Eele: the electrostatic interaction with the receptor, Evdw: van der Waals energies between the ligand and the receptor, Esol.: Solvation energy. 
for the most stable docking model to evaluate the binding affinities of the inhibitors, which complexes with (14DM) active sites, table (1). The complexes were energy-minimized with an MMFF94 force field $^{26}$ until the gradient convergence $0.05 \mathrm{kcal} / \mathrm{mol}$ was reached. All isolated compounds were docked successfully, and compared with reference inhibitor (phenylimidazol 1), and exhibited that, the highest MOE binding scores for synthesized compounds $15<16<4 \mathrm{a}<4 \mathrm{~b} \mathrm{Kcal} / \mathrm{mol}$, respectively, (table 1).

The other parameters like hydrogen interaction energy, electrostatic interaction with the receptor, van der Waals and salvation energy were also taken into consideration for the evaluation of the docking results; the values of the energy and E-model were found to be significant, and accepted this fact that, a good van der Waals interactions decides the binding affinity for any ligand with receptor enzyme protein, and bad van der waals interactions shows ugly contacts through steric clashes after docking which should be less for good activity.

\section{Structures activity relationships}

In order to get a deeper insight into the nature and type of interactions of docked compounds, the complexes between each compound and (14DM) receptor were visualized, and depicted in (Figs. 1 and 2). Since, the $\mathrm{H}$ bond interactions playing an important role in the structure and function of biological molecules, the current ligand-receptor interactions were analyzed on the basis of $\mathrm{H}$ bonding. In order to reduce the complexity, hydrophobic and $\pi$-cation interactions (>6̊) are not shown in (Figs. 1 and 2).

The results obtained clearly revealed that, the amino acid residues close to the reference molecules phenylimidazol (1) are mostly the same as observed in the currently compounds under investigation, which complexes with proteins . The higher binding energies and binding process interaction were observed in case of compounds $4 a$, 4b,15 and 16 act as inhibitors against (14DM).

\section{EXPERIMENTAL}

All melting points and antimicrobial activities are uncorrected. IR spectra $(\mathrm{KBr})$ were recorded on FT-IR 5300 spectrometer and Perkin Elmer spectrum RXIFT-IR system (í, $\mathrm{cm}^{-1}$ ). The ${ }^{1}$ HNMR spectra were recorded in $\left(\mathrm{CDCl}_{3}\right.$ \& DMSO- $\left.\mathrm{d}_{6}\right)$ at $(300) \mathrm{MHz}$ on a Varian Mercury VX-300 NMR spectrometer (ä, ppm) using TMS as an internal standard. Mass spectra were obtained on GC Ms-QP 1000 EX mass spectrometer at $70 \mathrm{ev}$. Elemental analyses were carried out by the Micro analytical Research Center, Faculty of Science, Cairo University.

1-\{(5Z)-5-[(4-methoxyphenyl)imino]-4-phenyl-4,5dihydro-1,3,4-thiadiazol-2-yl\}ethanone 3

A mixture of $(1 ; 0.01 \mathrm{~mol})$ and hydrazonoyl chloride $2(0.01 \mathrm{~mol})$ in ethanol $(50 \mathrm{ml})$ triethylamine $(0.5 \mathrm{ml})$ was added. The reaction mixture was refluxed for $3 \mathrm{~h}$. The resulting product was collected by filtration and recrystallized from $\mathrm{EtOH}$ to give $\mathbf{3}$ as yellow crystals .(yield 78\%), m.p.130-132, ir $\left(\mathrm{vcm}^{-1}\right)$ : 3076(CH-arom.) , 2958 (CH-aliph.) and 1678 $(\mathrm{C}=\mathrm{O}),{ }^{1} \mathrm{H}$ NMR $\left(300 \mathrm{MHz}\right.$ ä ppm $\left.\mathrm{CDCl}_{3}\right) 2.61(\mathrm{~s}, 3 \mathrm{H}$, $\left.\mathrm{COCH}_{3}\right), 3.81\left(\mathrm{~s}, 3 \mathrm{H}, \mathrm{OCH}_{3}\right), 6.91,6.97(\mathrm{dd}, 4 \mathrm{H}, \mathrm{Ar}-\mathrm{H}$ AB-system ) $7.39(\mathrm{~m}, 1 \mathrm{H}, \mathrm{Ar}-\mathrm{H}), 7.50(\mathrm{~m}, 2 \mathrm{H}, \mathrm{Ar}-\mathrm{H})$ and $8.01(\mathrm{~d}, 2 \mathrm{H}, \mathrm{Ar}-\mathrm{H}) . \mathrm{ms}, \mathrm{m} / \mathrm{z}$ (intensity \%) 325 (15.7).M.F. $\mathrm{C}_{17} \mathrm{H}_{15} \mathrm{~N}_{3} \mathrm{O}_{2}$ S. Calculated: C, 62.75, H, 4.65, N, 12.91. Found: C, 62.69, H, 4.60, N, 12. 87 .

Reaction of acetylthiadiazole with
hydrazincarbodithioate
General procedure
$\quad$ A mixture of acetylthiadiazole $(0.01 \mathrm{~mol})$ and alkyl hydrazine carbodithioate $(0.012 \mathrm{~mol})$ in ethanol $(50 \mathrm{ml})$ was refluxed for one hour. The separated solid on heating was filtered off and recrystallized from the proper solvent to give $(4 a, b)$.

Methyl (E)-2-(1-((z)-5-((4-methoxyphenyl)imino)4-phenyl-4,5-dihydro-1,3,4-thiadiazol-2-yl) ethylidene)hydrazine-1-carbodithioate $4 a$

acetylthiadiazole $(0.01 \mathrm{~mol})$ and methyl hydrazine carbodithioate $(0.012 \mathrm{~mol})$ recrystallized from EtOH to give $4 a$ as yellow crystals .(yield 84\%), m.p.212$\left.214^{\circ} \mathrm{C}, \mathrm{ir}_{\left(\mathrm{vcm}^{-1}\right)}\right): 3159(\mathrm{NH}), 3088(\mathrm{CH}$-arom.) and 2907 (CH-aliph.). ${ }^{1} \mathrm{H} ~ \mathrm{NMR}\left(300 \mathrm{MHz} \delta \mathrm{ppm} \mathrm{CDCl}_{3}\right) 2.37$ (s, $\left.3 \mathrm{H}, \mathrm{CH}_{3} \mathrm{C}=\mathrm{N}\right), 2.62\left(\mathrm{~s}, 3 \mathrm{H}, \mathrm{SCH}_{3}\right) 3.73\left(\mathrm{~s}, 3 \mathrm{H}, \mathrm{OCH}_{3}\right)$, 7.16-7.97 (m, 9H, Ar-H), and 9.99(s,1H,NH). M.F. $\mathrm{C}_{19} \mathrm{H}_{19} \mathrm{~N}_{5} \mathrm{OS}_{3}$. Calculated: $\mathrm{C}, 53.12, \mathrm{H}, 4.46, \mathrm{~N}, 16.30$. Found: C, 53.09, H, 4.43, N, 16. 25 .

Benzyl (E)-2-(1-((Z)-5-((4-methoxyphenyl)imino)4-phenyl-4,5-dihydro-1,3,4-thiadiazol-2-yl) ethylidene)hydrazine-1-carbodithioate $4 \mathrm{~b}$ acetylthiadiazole $(0.01 \mathrm{~mol})$ and benzyl hydrazine carbodithioate $(0.012 \mathrm{~mol})$ recrystallized 
from $\mathrm{EtOH}$ to give $\mathbf{4 b}$ as yellow crystals .(yield $81 \%$ ), m.p.207-209 ${ }^{\circ} \mathrm{C}, \operatorname{ir}\left(\mathrm{vcm}^{-1}\right): 3174(\mathrm{NH}), 3098(\mathrm{CH}-$ arom.) and 2870 (CH-aliph.). ${ }^{1} \mathrm{H} \mathrm{NMR}(300 \mathrm{MHz} \delta \mathrm{ppm}$ $\left.\mathrm{CDCl}_{3}\right) 2.36\left(\mathrm{~s}, 3 \mathrm{H}, \mathrm{CH}_{3} \mathrm{C}=\mathrm{N}\right), 2.61\left(\mathrm{~s}, 3 \mathrm{H}, \mathrm{SCH}_{3}\right) 3.75$ $\left(\mathrm{s}, 3 \mathrm{H}, \mathrm{OCH}_{3}\right), 4.53\left(\mathrm{~s}, 2 \mathrm{H}, \mathrm{CH}_{2}\right) 7.10-7.93(\mathrm{~m}, 14 \mathrm{H}, \mathrm{Ar}-$ $\mathrm{H}$ ), and 9.93(s,1H,NH). M.F. $\mathrm{C}_{25} \mathrm{H}_{23} \mathrm{~N}_{5} \mathrm{OS}_{3}$. Calculated: C, 73.33, H, 5.66, N, 17.1. Found: C, 73.29, H, 5.59, N, 17.04.

\section{Synthesis of 8 a,b}

A mixture of $(4 a, b ; 0.01 \mathrm{~mol})$ and the appropriate hydrazonoyl halide $(0.01 \mathrm{~mol})$ in ethanol $(50 \mathrm{ml})$ triethylamine $(0.5 \mathrm{ml})$ was added .The reaction mixture was refluxed for $3 \mathrm{~h}$. The resulting product was collected by filtration and recrystallized from the proper solvent to give 8 .

1-((Z)-5-(((Z)-2-((Z)-5-((4-methoxyphenyl)imino)4-phenyl-4,5-dihydro-1,3,4-thiadiazol-2-yl) prop-1-en-1-yl)imino)-4-phenyl-4,5-dihydro-1,3,4thiadiazol-2-yl)ethan-1-one $8 \mathrm{a}$

$3(0.01 \mathrm{~mol})$ and(1E)-2-oxo-Nphenylpropanehydrazonoyl chloride $(0.01 \mathrm{~mol})$ recrystallized from benzene to give $\mathbf{8 a}$ as yellow crystals .(yield $76 \%)$, m.p. $200-202^{\circ} \mathrm{C}$, $\operatorname{ir}\left(\mathrm{vcm}^{-1}\right)$ : 3088(CH-arom.) , 2932 (CH-aliph.) and1685(CO). ${ }^{1} \mathrm{H}$ $\operatorname{NMR}(300 \mathrm{MHz} \delta \mathrm{ppm} \mathrm{CDCl}) 2.32\left(\mathrm{~s}, 3 \mathrm{H}, \mathrm{CH}_{3} \mathrm{C}=\mathrm{N}\right)$, $2.49\left(\mathrm{~s}, 3 \mathrm{H}, \mathrm{COCH}_{3}\right) 3.81\left(\mathrm{~s}, 3 \mathrm{H}, \mathrm{OCH}_{3}\right), 7.02-7.99(\mathrm{~m}$, $9 \mathrm{H}, \mathrm{Ar}-\mathrm{H}$ ), and 9.93(s,1H,NH). M.F. $\mathrm{C}_{25} \mathrm{H}_{23} \mathrm{~N}_{5} \mathrm{OS}_{3}$. Calculated: C, 73.33, H, 5.66, N, 17.1. Found: C, 73.29, H, 5.59, N, 17. 04 .

((Z)-5-(((Z)-2-((Z)-5-((4-methoxyphenyl)imino)4-phenyl-4,5-dihydro-1,3,4-thiadiazol-2-yl) prop-1-en-1-yl)imino)-4-phenyl-4,5-dihydro-1,3,4thiadiazol-2-yl)(phenyl)methanone 8b.

$3(0.01 \mathrm{~mol})$ and $(1 Z)-2-0 \times 0-N, 2-$ diphenylethanehydrazonoyl bromide $(0.01 \mathrm{~mol})$ recrystallized from benzene to give $\mathbf{8 b}$ as yellow crystals .(yield $75 \%)$, m.p. $177-179^{\circ} \mathrm{C}$, ir $\left(\mathrm{vcm}^{-1}\right)$ : 3084(CH-arom.) 2931 (CH-aliph.) and1678(CO). ${ }^{1} \mathrm{H}$ $\operatorname{NMR}(300 \mathrm{MHz} \delta \mathrm{ppm} \mathrm{CDCl}) 2.32\left(\mathrm{~s}, 3 \mathrm{H}, \mathrm{CH}_{3} \mathrm{C}=\mathrm{N}\right)$, $3.74\left(\mathrm{~s}, 3 \mathrm{H}, \mathrm{OCH}_{3}\right), 7.03-8.20(\mathrm{~m}, 19 \mathrm{H}, \mathrm{Ar}-\mathrm{H})$, and 9.93(s,1H,NH). M.F. $\mathrm{C}_{25} \mathrm{H}_{23} \mathrm{~N}_{5} \mathrm{OS}_{3}$. Calculated: C, 73.33, H, 5.66, N, 17.1. Found: C, 73.29, H, 5.59, N, 17. 04 .

3-(dimethylamino)-1-((Z)-5-((4-methoxyphenyl) imino)-4-phenyl-4,5-dihydro-1,3,4-thiadiazol-2-yl) prop-2-en-1-one 9

A mixture of acetylthiadiazole $(3 ; 0.01 \mathrm{~mol})$ and DMF-DMA (0.012 mol) in dry benzene $(40 \mathrm{ml})$ was heated under reflux for $5 \mathrm{hrs}$. the separated solid was filtered off, washed with ethanol and recrystallized from benzene, orange crystals .(yield 77\%), m.p. $165-166^{\circ} \mathrm{C}, \mathrm{ir}\left(\mathrm{vcm}^{-1}\right): 2924$ ( $\mathrm{CH}$-aliph.) and $1662(\mathrm{C}=\mathrm{O}),{ }^{1} \mathrm{H}$ NMR $\left(300 \mathrm{MHz} \delta \mathrm{ppm} \mathrm{CDCl}{ }_{3}\right)$ 2.96 and $3.17\left(2 \mathrm{~s}, 6 \mathrm{H}, \mathrm{N}\left(\mathrm{CH}_{3}\right)_{2}\right), 3.81\left(\mathrm{~s}, 3 \mathrm{H}, \mathrm{OCH}_{3}\right)$ 5.86 and $7.85(\mathrm{dd}, 2 \mathrm{H}$, olefinic $\mathrm{CH}=\mathrm{CH} ; \mathrm{J}=12$ $\mathrm{Hz}), 6.89$, 7.02(dd, 4H, Ar-H AB-system ) 7.31 (m, $1 \mathrm{H}, \mathrm{Ar}-\mathrm{H}), 7.47(\mathrm{~m}, 2 \mathrm{H}, \mathrm{Ar}-\mathrm{H})$ and $8.02(\mathrm{~d}, 2 \mathrm{H}, \mathrm{Ar}-$ H), $C^{13} \mathrm{NMR}(\mathrm{DMSO}-\mathrm{d} 6): \delta=175.01,155.77,155.64$, $154.55,150.38,144.62,139.01,128.74,126.65$ , 122.94, 121.37, 120.77, 120.71, 114.78, 88.23, $55.16,44.78,40.1$ and $39.55(2 \mathrm{C})$. $\mathrm{ms}, \mathrm{m} / \mathrm{z}$ (intensity \%) 293 (82.7).M.F. C ${ }_{13} \mathrm{H}_{12} \mathrm{BrNO}_{2}$. Calculated: C, 53.08, H, 4.11, N, 4.76. Found: C, 53.01, H, 4.08, $\mathrm{N}, 4.69$.

\section{Reaction of acylglycine with enaminone 9}

A mixture of enaminone $9(0.01 \mathrm{~mol})$ and acetylglycine or benzoylglycine $(0.01 \mathrm{~mol})$ in acetic anhydride $(30 \mathrm{ml})$ was heated under reflux for $2 \mathrm{~h}$. The reaction mixture was concentrated in vacuo. The solid product which formed upon cooling was filtered off then washed with ethanol and recrystallized from the appropriate solvents to give $(10 a, b)$.

$\mathrm{N}-(6-\{(5 Z)-5-[(4-m e t h o x y p h e n y l) i m i n o]-4-p h e n y l-$ 4,5-dihydro-1,3,4-thiadiazol-2-yl\}-2-oxo-2Hpyran-3-yl)acetamide 10a

Recrystallized from benzene. (yield $74 \%$ ), m.p. $242-244^{\circ} \mathrm{C}$, ir $\left(\mathrm{vcm}^{-1}\right): 3323(\mathrm{NH}), 1720$ and 1673 $(2 \mathrm{C}=\mathrm{O}),{ }^{1} \mathrm{H}$ NMR $(300 \mathrm{MHz} \delta \mathrm{ppm}$ DMSO-d6) 2.13 $\left(\mathrm{s}, 3 \mathrm{H}, \mathrm{CH}_{3}\right), 3.74\left(\mathrm{~s}, 3 \mathrm{H}, \mathrm{OCH}_{3}\right), 6.91-7.51(\mathrm{~m}, 9 \mathrm{H}$, $\mathrm{Ar}-\mathrm{H}$ ), 7.94 and 8.20 (dd, $2 \mathrm{H}$ pyranone; $\mathrm{J}=7.8 \mathrm{~Hz}$ ), 9.85 (s, 1H, NH), $\mathrm{C}^{13} \mathrm{NMR}(\mathrm{DMSO}-\mathrm{d} 6)$ : ä $=170.35$, 156.59, 156.04, 153.38, 144.52, 143.07, 138.84, $138.45,128.23,126.60,122.41,121.33,114.89$, $106.59,55.19,40.37,39.81,38.70$, M.F. ${ }_{22} \mathrm{H}_{18} \mathrm{~N}_{4} \mathrm{O}_{4} \mathrm{~S}$ Calculated: C, 65.34, H, 4.98, N, 13.85. Found: C, 65.30, H, 4.95, N, 13.83.

$\mathrm{N}-(6-\{(5 Z)-5-[(4-m e t h o x y p h e n y l) i m i n o]-4-p h e n y l-$ 4,5-dihydro-1,3,4-thiadiazol-2-yl\}-2-oxo-2Hpyran-3-yl)benzamide 10b

Recrystallized from benzene. (yield $81 \%$ ), m.p. $233-235^{\circ} \mathrm{C}$, ir $\left(\mathrm{vcm}^{-1}\right): 3386(\mathrm{NH}), 1719$ and 1668(2C=O), ${ }^{1} \mathrm{H}$ NMR (300MHz $\delta \mathrm{ppm}$ DMSO-d6) $3.78\left(\mathrm{~s}, 3 \mathrm{H}, \mathrm{OCH}_{3}\right), 6.95-7.85(\mathrm{~m}, 9 \mathrm{H}, \mathrm{Ar}-\mathrm{H}), 7.83$ and $8.11(\mathrm{dd}, 2 \mathrm{H}$ pyranone; $\mathrm{J}=7.5 \mathrm{~Hz}), 9.90(\mathrm{~s}, 1 \mathrm{H}, \mathrm{NH})$. 
ms, $m / z$ (intensity \%) 496 (32.9). M.F: $\mathrm{C}_{27} \mathrm{H}_{20} \mathrm{~N}_{4} \mathrm{O}_{4} \mathrm{~S}$ Calculated: C, 69.82, H, 4.34, N, 12.06 Found: C, 69.78, H, 4.31, N, 12.02 .

(Z)-3-(5-((4-methoxyphenyl)imino)-4-phenyl-4,5dihydro-1,3,4-thiadiazol-2-yl)benzofuran-5-ol (11).

To a stirred solution of enaminone 9 (0.01 $\mathrm{mol})$ in glacial acetic acid $(25 \mathrm{ml}), 1,4$-benzoquionone $(0.01 \mathrm{~mol})$ was added, stirring was continued for $3 \mathrm{~h}$. at room temperature. The reaction mixture was evaporated in vacuo and the solid product was isolated by filtration and recrystallized from acetic acid (yield 68\%), m.p.189-190 ${ }^{\circ} \mathrm{C}$, ir $\left(\mathrm{vcm}^{-1}\right)$ : $3380(\mathrm{OH}) ;{ }^{1} \mathrm{H}$ NMR $(300 \mathrm{MHz} \delta$ ppm DMSO-d6) 3.76(s,3H, $\left.\mathrm{OCH}_{3}\right), 6.87-8.05(\mathrm{~m}, 12 \mathrm{H}, \mathrm{Ar}-\mathrm{H}), 9.12$ (s, $1 \mathrm{H}$ furan), 9.52 (s, $1 \mathrm{H}, \mathrm{OH}$ ). $\mathrm{ms}, \mathrm{m} / \mathrm{z}$ (intensity \%) 399 (8.5). M.F: $\mathrm{C}_{23} \mathrm{H}_{17} \mathrm{~N}_{3} \mathrm{O}_{3}$ S. Calculated: C, 69.17, H, 4.29, N, 10.52 Found: C, 69.13, H, 4.26, N, 10.48 .

(Z)-1-(5-((4-methoxyphenyl)imino)-4-phenyl4,5-dihydro-1,3,4-thiadiazol-2-yl)benzo[4,5] imidazo[1,2-a]pyridine-4-carbonitrile 12

A mixture of enaminone $(9 ; 0.01 \mathrm{~mol})$ and 2-cyanomethyl benzoimidazole $(0.01 \mathrm{~mol})$ in glacial acetic acid $(30 \mathrm{ml})$ was refluxed for $3 \mathrm{hrs}$. the solid product which obtained after cooling was collected by filtration and recrystallized from EtOH (yield $64 \%)$, m.p. $148-150^{\circ} \mathrm{C}$, ir $\left(\mathrm{vcm}^{-1}\right): 2200(\mathrm{CN}){ }^{1} \mathrm{H}$ NMR (300MHz $\delta$ ppm DMSO-d6) 3.77(s,3H, $\left.\mathrm{OCH}_{3}\right), 6.96-$ $8.42(\mathrm{~m}, 15 \mathrm{H}, \mathrm{Ar}-\mathrm{H}), \mathrm{m} / \mathrm{z}$ (intensity \%) 426 (5.7). M.F: $\mathrm{C}_{27} \mathrm{H}_{18} \mathrm{~N}_{6} \mathrm{OS}$. Calculated: $\mathrm{C}, 76.04, \mathrm{H}, 4.25, \mathrm{~N}, 19.71$ Found: C, 76.01, H, 4.23, N, 19.68 .

Diethyl (Z)-2-hydroxy-4-(5-((4-methoxyphenyl) imino)-4-phenyl-4,5-dihydro-1,3,4-thiadiazol-2-yl) isophthalate 13

A mixture of enaminone $(9 ; 0.01 \mathrm{~mol})$ and diethyl acetonedicarboxylate $(0.01 \mathrm{~mol})$ in glacial acetic acid $(30 \mathrm{ml})$ was refluxed for $2 \mathrm{~h}$. the solid product which obtained after cooling was collected by filtration and recrystallized from EtOH (yield $66 \%$ ), m.p.170-172 $\mathrm{C}$, ir $\left(\mathrm{vcm}^{-1}\right): 1725$ (CO); ${ }^{1} \mathrm{H}$ NMR $(300 \mathrm{MHz} \delta$ ppm CDCl $) 1.25\left(\mathrm{t}, 3 \mathrm{H}, \mathrm{CH}_{2} \mathrm{CH}_{3}\right)$ $1.43\left(\mathrm{t}, 3 \mathrm{H}, \mathrm{CH}_{2} \mathrm{CH}_{3}\right), 3.82\left(\mathrm{~s}, 3 \mathrm{H}, \mathrm{OCH}_{3}\right), 4.31(\mathrm{q}, 2 \mathrm{H}$, $\left.\mathrm{CH}_{2} \mathrm{CH}_{3}\right), 4.44\left(\mathrm{q}, 2 \mathrm{H}, \mathrm{CH}_{2} \mathrm{CH}_{3}\right), 6.92-7.94(\mathrm{~m}$, $11 \mathrm{H}, \mathrm{Ar}-\mathrm{H})$, and $11.30(\mathrm{~s}, 1 \mathrm{H}, \mathrm{OH}) \mathrm{M} . \mathrm{F}: \mathrm{C}_{27} \mathrm{H}_{24} \mathrm{~N}_{3} \mathrm{O} 6 \mathrm{~S}$. Calculated: C, 66.66, H, 4.97, N, 8.64 Found: C, $66.61, \mathrm{H}, 4.93, \mathrm{~N}, 8.63$.
Ethyl (Z)-4-(5-((4-methoxyphenyl)imino)-4phenyl-4,5-dihydro-1,3,4-thiadiazol-2-yl)-2methylbenzoate 14

To a solution of enaminone $9(0.01 \mathrm{~mol})$ and acetyl acetone $(0.01 \mathrm{~mol})$ in acetic acid $(20 \mathrm{~mL})$ was added ammonium acetate $(0.02 \mathrm{~mol})$. The reaction mixture was heated under reflux for $3 \mathrm{~h}$. After cooling, the solid product was collected by filtration and crystallized from ethanol (yield71\%) ; m.p.118$120^{\circ} \mathrm{C}$, ir $\left(\mathrm{vcm}^{-1}\right): 1677$ (CO); ${ }^{1} \mathrm{H}$ NMR $(300 \mathrm{MHz} \delta$ ppm $\left.\mathrm{CDCl}_{3}\right) 2.62\left(\mathrm{~s}, 3 \mathrm{H}, \mathrm{CH}_{3}\right) 2.73\left(\mathrm{~s}, 3 \mathrm{H}, \mathrm{COCH}_{3}\right)$, $3.82\left(\mathrm{~s}, 3 \mathrm{H}, \mathrm{OCH}_{3}\right)$ and $6.94-8.06(\mathrm{~m}, 11 \mathrm{H}, \mathrm{Ar}-\mathrm{H})$ M.F: $\mathrm{C}_{23} \mathrm{H}_{18} \mathrm{~N}_{4} \mathrm{O}_{2} \mathrm{~S}$. Calculated: C, $61.88, \mathrm{H}, 4.06, \mathrm{~N}$, 12.55 Found: $\mathrm{C}, 61.85, \mathrm{H}, 4.03, \mathrm{~N}, 12.51$.

(Z)-2,4-diamino-5-(5-((4-methoxyphenyl)imino)-4phenyl-4,5-dihydro-1,3,4-thiadiazole-2-carbonyl) isophthalonitrile 15

A mixture of enaminone $9(0.01 \mathrm{~mol})$ and 3-amino-2-cyanopent-2-enedinitrile $(0.01 \mathrm{~mol})$ in dioxan $(25 \mathrm{~mL})$ containing $1 \mathrm{ml}$ of triethyl amine was heated under reflux for $3 \mathrm{~h}$ (followed until completion by TLC using 1:1 ethyl acetate-petroleum ether as eluent). The mixture was then cooled. The solid, so formed, was collected by filtration and crystallized from $\mathrm{AcOH}$ (yield 62\%); m.p.280$282^{\circ} \mathrm{C}$, ir $\left(\mathrm{vcm}^{-1}\right): 3406,3331\left(\mathrm{NH}_{2}\right), 2211(\mathrm{CN})$ and1649(CO), ${ }^{1} \mathrm{H}$ NMR (300MHz ä ppm DMSO-d6) 3.77( $\left(\mathrm{s}, 3 \mathrm{H}, \mathrm{OCH}_{3}\right), 4.09\left(\mathrm{~s}, 4 \mathrm{H}, 2 \mathrm{NH}_{2}\right)$ 6.96-7.89 (m, $10 \mathrm{H}, \mathrm{Ar}-\mathrm{H}$ ); ms, $\mathrm{m} / \mathrm{z}$ (intensity \%) 576 (32.9); M.F: $\mathrm{C}_{24} \mathrm{H}_{17} \mathrm{~N}_{7} \mathrm{O}_{2}$ S. Calculated: C, 66.05, H, 4.16, N, 22.46 Found: C, 66.02, H, 4.12, N, 22.43.

(Z)-7-(5-((4-methoxyphenyl)imino)-4-phenyl4,5-dihydro-1,3,4-thiadiazol-2-yl)-2-(methylthio) pyrazolo[1,5-a]pyrimidine-3-carbonitrile 16

A mixture of enaminone $9(0.01 \mathrm{~mol})$ and 5-amino-3-(methylsulfanyl)- $1 \mathrm{H}$-pyrazole-4carbonitrile $(0.01 \mathrm{~mol})$, in glacial acetic acid $(20$ $\mathrm{mL}$ ), was refluxed for $3 \mathrm{~h}$. The solid that formed was filtered off, and crystallized from ethanol to afford compounds 16 (yield $73 \%$ ); m.p. $170-172^{\circ} \mathrm{C}$, ir ( $\left.\mathrm{vcm}^{-1}\right)$ : 2226(CN), ${ }^{1} \mathrm{H}$ NMR (300MHz ä ppm $\mathrm{CDCl}_{3}$ ) $2.48\left(\mathrm{~s}, 3 \mathrm{H}, \mathrm{SCH}_{3}\right) 3.80\left(\mathrm{~s}, 3 \mathrm{H}, \mathrm{OCH}_{3}\right)$ and $6.90-8.29$ ( $\mathrm{m}, 11 \mathrm{H}, \mathrm{Ar}-\mathrm{H}$, pyrimidine- $\mathrm{H}$ ); $\mathrm{ms}, \mathrm{m} / \mathrm{z}$ (intensity \%) 407 (12.5) M.F: $\mathrm{C}_{23} \mathrm{H}_{17} \mathrm{~N}_{7} \mathrm{OS}_{2}$ Calculated: C, 60.64, H, 3.76, N, 21.52 Found: C, 60.61, H, 3.73, N, 21.47. 
Ethyl (Z)-6-(5-((4-methoxyphenyl)imino)-4phenyl-4,5-dihydro-1,3,4-thiadiazol-2-yl)-2methylnic otinate 18

To a solution of enaminone $9(0.01 \mathrm{~mol})$ and ethyl 3-oxobutanoate $(0.01 \mathrm{~mol})$ in acetic acid (20 $\mathrm{mL}$ ) was added ammonium acetate $(0.02 \mathrm{~mol})$. The reaction mixture was heated under reflux for $2 \mathrm{~h}$. After cooling, the solid product was collected by filtration and crystallized from ethanol (yield 76\%); m.p.130$132^{\circ} \mathrm{C}$, ir $\left(\mathrm{vcm}^{-1}\right): 1720(\mathrm{CO}),{ }^{1} \mathrm{H}$ NMR $(300 \mathrm{MHz} \delta$ ppm $\left.\mathrm{CDCl}_{3}\right)$ 1.42(t,3H, $\left.\mathrm{CH}_{2} \mathrm{CH}_{3}\right), 2.81\left(\mathrm{~s}, 3 \mathrm{H}, \mathrm{CH}_{3}\right)$, $3.83\left(\mathrm{~s}, 3 \mathrm{H}, \mathrm{OCH}_{3}\right), 4.39\left(\mathrm{q}, 2 \mathrm{H}, \mathrm{CH}_{2} \mathrm{CH}_{3}\right), 6.92$, 7.02(dd, 4H, Ar-H AB-system; = 8.4Hz) $7.33(\mathrm{~m}$, $1 \mathrm{H}, \mathrm{Ar}-\mathrm{H}), 7.49(\mathrm{~m}, 2 \mathrm{H}, \mathrm{Ar}-\mathrm{H})$ 7.97(d,2H,Ar-H), (dd, $2 \mathrm{H}$, pyridine- $\mathrm{H} ; \mathrm{J}=8.4 \mathrm{~Hz}$ ); M.F: $\mathrm{C}_{24} \mathrm{H}_{20} \mathrm{~N}_{4} \mathrm{O}_{3} \mathrm{~S}$ Calculated: C, 60.49, H, 4.23, N, 11.76 Found: C, 60.46, H, 4.19, $\mathrm{N}, 11.73$.

\section{Synthesis of $23 a, b$}

To a mixture of enaminone $9(0.01 \mathrm{~mol})$ and the hydrazonoyl halide $19 a, b(0.01 \mathrm{~mol})$ in benzene $(30 \mathrm{ml})$ an equivalent amount of triethylamine was added. The reaction mixture was heated under reflux for $3 \mathrm{~h}$. the solvent was distilled at reduced pressure and the residual viscous liquid was taken in ethanol then the resulting solid was collected by filtration, washed thoroughly with ethanol, dried and finally crystallized from ethanol to give $\mathbf{2 3 a} \mathbf{a}, \mathbf{b}$.

Methyl (E)-4-(5-((4-methoxyphenyl)imino)-4phenyl-4,5-dihydro-1,3,4-thiadiazole-2-carbonyl)1-phenyl-1H-pyrazole-3-carboxylate 23a

(yield 64\%); m.p.144-145 C; ir (vcm $\left.{ }^{-1}\right): 1696$

(CO), ${ }^{1} \mathrm{H}$ NMR (300MHz $\delta$ ppm $\left.\mathrm{CDCl}_{3}\right) 2.68$ (s, 3H, $\mathrm{CH}_{3}$ ), 3.82(s, 3H, $\left.\mathrm{OCH}_{3}\right), 6.91-8.08(\mathrm{~m}, 14 \mathrm{H}, \mathrm{Ar}-\mathrm{H})$, 8.52 (s, $1 \mathrm{H}$, pyrazole-H5); calcd for $\mathrm{C}_{27} \mathrm{H}_{21} \mathrm{~N}_{5} \mathrm{O}_{3} \mathrm{~S}: \mathrm{C}$,
65.44, H, 4.27, N, 14.13 Found: C, 65.40, H, 4.25, N, 14.09.

(E)-(3-benzoyl-1-phenyl-1H-pyrazol-4-yl) (5-((4-methoxyphenyl)imino)-4-phenyl-4,5dihydro-1,3,4-thiadiazol-2-yl)methanone 23b

(yield 66\%); m.p.148-150 $\mathrm{C}$; ir $\left(\mathrm{vcm}^{-1}\right)$ : 1656 (CO) ; ${ }^{1} \mathrm{H}$ NMR (300MHz $\delta$ ppm $\left.\mathrm{CDCl}_{3}\right) 3.80$ (s, $\left.3 \mathrm{H}, \mathrm{OCH}_{3}\right), 6.88-8.02(\mathrm{~m}, 14 \mathrm{H}, \mathrm{Ar}-\mathrm{H}), 8.58$ (s, $1 \mathrm{H}$, pyrazole-H5); calcd for $\mathrm{C}_{32} \mathrm{H}_{23} \mathrm{~N}_{5} \mathrm{O}_{3} \mathrm{~S}: \mathrm{C}, 69.18$, $\mathrm{H}, 3.81, \mathrm{~N}, 12.60$. Found: C, 69.15, H, 3.78, N, 12.57

\section{(E)-N-(4-methoxyphenyl)-5-(7-methyl-2-phenyl-} 2H-pyrazolo[3,4-d]pyridazin-4-yl)-3-phenyl-1,3,4thiadiazol-2(3H)-imine 24

A mixture of pyrazole derivative 23a $(0.01$ $\mathrm{mol})$ and hydrazine hydrate $(0.012 \mathrm{~mol})$ in ethanol $(40 \mathrm{ml})$ was heated under reflux for $2 \mathrm{~h}$. The separated solid was filtered off, washed with ethanol and crystallized from ethanol (yield71\%); m.p.248-250 $\mathrm{C}$; ir $\left(\mathrm{vcm}^{-1}\right): 1608(\mathrm{C}=\mathrm{N}) ;{ }^{1} \mathrm{H}$ NMR $(300 \mathrm{MHz}$ ä ppm DMSO-d6) 2.23(s,3H, $\left.\mathrm{CH}_{3}\right), 3.79\left(\mathrm{~s}, 3 \mathrm{H}, \mathrm{OCH}_{3}\right), 6.72-$ 7.81 (m, 14H, Ar-H), 8.43 (s, 1H, pyrazole-H5); ms: $\mathrm{m} / \mathrm{z}$ (intensity \%) 491 (74.4); calcd for $\mathrm{C}_{27} \mathrm{H}_{21} \mathrm{~N}_{7} \mathrm{OS}$ : C, 61.94, H, 4.04, N, 18.73. Found: C, 61.91, H, 4.02, N, 18.69 .

\section{CONCLUSION}

1,3,4-thiadiazolyl ethanone is a good starting material for the synthesis of different heterocyclic derivatives which gave a good results when tested against tuberculosis especially poly substituted benzene 15 ,pyrazolopyrimidine 16 and hydrazone 4 derivatives .

\section{REFERENCES}

1. kandapalli, V.G.; Vajja,S.R. Bull. Korean Chem. soc. 2010, 35, 1219-1222.

2. Feray, A.; Cigdem, Y. Bull. Korean Chem. soc. 2001, 22, 476-480.

3. Dogan, H. N.; Rollas, S.; Erdeniz, H. , IL Farmaco 1998, 53, 462-467.

4. Dogan, H. N. ; Duran A.; Rollas, S.; Sener, G.; Uysal, M. K.; Gulen D. Bioorg. Med.Chem. 2002 , 10, 2893-2898.

5. Palaska, E.; Sahin, G. ; Kelicen, P. ; Turlu, N.
T. ; Altinok G. IL Farmaco 2002, 57,101-107.

6. Karakus, S. ; Rollas, S. IL Farmaco 2002, 57, 577-581.

7. Zareba, S. Pharmazie 1993, 48, 782-783.

8. - Gao, Y. J. ; Zhang, Z. J.; Xue, Q. J. Mater. Res. Bull. 1999, 34, 1867-1874.

9. Choi, U. S.; Kim, T. W.; Jung, S. W. ; Kim C. J. Bull. Korean Chem. Soc. 1998, 19, 299-307.

10. Chen, S. L.; Ji, S. X.; Zhu, Z. H. ; Yao Z. G. Dyes Pigments 1993, 23, 275-283. 
11. Jin, G. Y.; Hou, Z.; Zhao, G. F.; Cao, C. Y. ; Li Y. C. Chem. J. Chin. Univ. 1997, 18, 409-412.

12. Lu, S. M.; Chen, R. Y. Org. Prep. Proced. Int. 2000, 32, 302-306.

13. Hui, X. P.; Zhang, L. M.; Zhang, Z. Y.; Wang, Q. ; Wang, F. Indian J. Chem. Sect. B, 1999 , 38, 1066-1069 .

14. Kumar, H.; Javed, S. A.; Khan, S. A. ; Amir, M. Eur. J. Med. Chem. 2008 , 43, 2688-26983.

15. Mullican, M. D.; Wilson, M. W.; Connor, D. T.; Kostlan, C. R.; Schrier, D. J. ; Dyer, R. D. J. Med. Chem. 1993, 36, 1090-1099.

16. Song, Y.; Connor, D. T.; Sercel, A. D.; Sorenson, R. J.; Doubleday R.; Unangst P. C.; Roth B.D.; Beylin, V. G.; Gilbertsen, R. B.; Chan, K.; Schrier D. J.; Guglietta, A.; Bornemeier, D. A.; Dyer, R. D. J. Med. Chem.
1999, 42, 1161-1169.

17. Danie,I L. K.; Joseph, F.; Scott, T. G.; Carl, J. M. ; John, P. S. J. Med. Chem., 1979 , 22, 855 -862 .

18. Korosi, J. Ger. Offen. 1, 934, 89929 Jan (1979), C. A. 72, 100334s (1970).

19. Eweiss, N. F.; Abdelhamide, A.O. J. Heterocyclic. Chem. 1980 , 17, 1713 -1717.

20. Shawali, A. S.; Abdelhamide, A. O. Bull. Soc. Japan 1976 , 49, 321-324.

21. Al-Zaydi, K.M. Molecules, 2003, 8 , 541-555.

22. Helmut, B.;, Irmgard, B. ; Joachim, F. K. Arch. Pharm. (Weinheim) 1983 , 316, 608-616.

23. El-Taweel, F.M. ; Elnagdi, M. H. J. Heterocyclic Chem. 2001, 38 , 981-984. 